\title{
Conflicts at Schools and Their Impact on Teachers
}

\author{
Süleyman Göksoy ${ }^{1}$, Türkan Argon ${ }^{2}$ \\ ${ }^{1}$ Düzce University, Faculty of Education, Düzce/Türkiye \\ ${ }^{2}$ Abant İzzet Baysal University, Faculty of Education, Bolu/Türkiye \\ Correspondence: Associate Prof. Dr. Süleyman Göksoy, Düzce University, Faculty of Education, Düzce, Türkiye
}

Received: December 17, 2015

Accepted: January 8, 2016 Online Published: February 17, 2016

doi:10.11114/jets.v4i4.1388

URL: http://dx.doi.org/10.11114/jets.v4i4.1388

\begin{abstract}
Based on teacher views, the study was set out to identify school conflicts, reasons behind them, their impact and responses to conflicts. The study undertaken via survey model utilized a qualitative research method. Study group of the study was composed of 57 classroom and subject matter teachers employed in Bolu central district during 2014-2015 academic year. Research data were collected with the help of semi-structured interview form and analyzed via content analysis. Some of the results obtained in the study are as follows: According to teachers, conflicts at schools are negative situations caused by differences of opinion and forming groups with like minded people based on inability to find common ground and disagreements, tension, unconformity, lack of communication and ideological clashes. Conflicts result mainly from lack of communication followed by personal, political-ideological and organizational factors. Conflicts have both negative and positive results in psychological, social and organizational aspects. Teachers who experience conflicts have negative feelings such as disappointment, insensitivity, stress, sorrow, uneasiness etc. and may dislike their professions, have low morale and motivation, form groups with like minded people and have reduced performance. Teachers who experience conflicts either respond, by arguing, evading the situation or using violence, or remain unresponsive.
\end{abstract}

Keywords: school conflicts, teachers

\section{Introduction}

Conflict, a social phenomenon that takes place between or among individuals, groups, organization and nations (Rubin, 1994), is an inseparable part of human and social life. Conflict, which is a process that occurs when an individual or a group realizes that their interests are obstructed or negatively influenced by others (Wall and Callester, 1995), is experienced as a result of disagreements and inconsistencies during interpersonal interactions (Rahim, 1983). Conflict which may occur as a result of various reasons between two or more persons or in a group (Koçel, 2003) consists of deliberately planned acts to prevent success in achieving goals (Taştan, 2004). As can be seen from the definitions, the concept of conflict is regarded as a negative situation and a process. At the same time, difficulties are experienced to select among options and deficiencies in decision making mechanisms are observed in this process (Can, 2002). In general, conflict is a two-dimensional dynamic process that needs to be perceived by the parties and there are difficulties in this process to select from among two or more options. The reasons for conflicts are disagreements, differences, friction and discrepancies based on differences of opinion, views and interests (İpek, 2000; Soyalp, 2001).

Conflicts, which are destructive phenomena to be avoided according to traditional view, are positive forces and necessary for organizations today to continue their existences (Robbins and Judge, 2012). Conflicts are not desired and generate failure simply because they are not managed well and therefore generate negative results. Therefore, the focus should be on how to manage the process instead of how to define it as a concept. In other words, how conflicts are resolved, which approach should be used and where it should be used to manage conflicts are crucial. Conflict management uses the following approaches: accommodating, compromise, collaborating, avoidance and confrontation (Rahim, 1992). In collaborating/integration approach the individual acts to satisfy his own needs without considering the influence of others and in compromise approach, he is believed to have the desire to fully satisfy the interest of the parties that take part in the conflict. In avoidance approach, the individual avoids the conflict or wants to suppress it although he is aware of the conflict. In accommodating approach, one of the parties in the conflict desires to value the other party's interests over his own (Thomas, 1992; Robbins and Judge, 2012).

The approaches used to resolve conflicts in a positive manner are crucial for organizational life because lack of success in conflict resolution will not only cause breakdown in the relationships among the personnel, it will also affect their performance, motivation and efforts negatively. Therefore conflicts will also reflect on organizational goals. In this 
context, it is crucial to take necessary precautions to prevent conflicts to occur and to generate and implement solutions to satisfy both parties in case conflicts occur. The most important role and responsibility in this process belongs to the managers as well as the individuals in conflict.

Conflicts which inevitably occurs in daily life everywhere where men life is an indispensable reality of school life where human relationships are experienced at the highest level. Many personnel and students with different characteristics spend their time together at schools. Conflict is inevitable between both teachers and students at schools where differences in culture, personality, values, beliefs, attitudes, needs, preferences, goals, interests and power come together. This is an important problem faced especially by teachers followed by management, counseling and guidance teachers and parents (Türnüklü, 2002). Today we have many positive and negative stimuli in terms of social and cultural, factors as well environmental and individual conditions, and conflict is one of the issues on which school administrators and teachers spend a lot of time. When they cannot acquire the necessary skills, administrators and teachers who cannot overcome conflict situations will be entrapped by one of the most important problems that can steal away the time that should be spent on instruction (Argon, 2014).

At schools conflicts may be experienced in many issues such as distribution of work among personnel, financial resources, in and out of class teaching activities and practices, rewards, punishment, assessment practices, use of power-authority, being late for class, leave of absences, political views, negative personal attitudes, passing grade levels and scoring system, issues regarding the legislation, student behaviors, dress code, assignments and placements for staff and distribution of resources (Karip, 2000). Conflicts can take place between administrators-teachers, teachers-teachers, teachers-stunts or parents-parents or among the students. It should be kept in mind that regardless of the type of conflict or the group that take part in it, conflicts will deepen and be more complicated unless they are resolved and people involved in the conflict will experience negative feelings (Argon, 2014). This will negatively affect the job performances of the personnel and will decrease the quality of education and training at schools. The current study, undertaken in line with the literature, examined and discussed the conflicts experienced at school based on teacher views. In this respect, the study aimed to determine teacher views regarding the conflicts experienced at schools, the reasons behind conflicts, the impact of conflict on teachers and the responses conflict generates.

\section{Method}

\subsection{Research Model}

The study that utilized the survey model made use of qualitative research method to identify teacher views related to conflict process at schools.

\subsection{Study Group}

Study group of the study was composed of 57 voluntary classroom and subject matter teachers employed in Bolu central district during 2014-2015 academic year. 23 of the teachers were females, 34 were males; 39 teachers had less than 10 year work experience and 18 had 11-20 years experience; 52 teachers had undergraduate degrees whereas 5 teachers had graduate degrees.

\subsection{Data Collection Tool}

Semi-structured interview form was used in the study as data collection tool. Related literature was reviewed during the development of the form, open-ended questions were prepared, and views of three experts in the field of educational sciences were taken prior to the pilot implementation which included the views of three teachers and three school principals. The finalized form was distributed to the voluntary teachers who were asked to respond in writing.

Interview form included four open-ended questions provided below:

1. What does school conflict mean?

2. What are the reasons behind school conflicts?

3. Are there positive or negative outcomes of school conflicts? What are they?

4. What are the effects of conflicts on teachers and how teachers respond to conflict?

\subsection{Data Analysis and Interpretation}

Data obtained in the study were analyzed with the help of content analysis. Data analysis started by coding interview forms as T1 (Teacher 1), T2 (Teacher 2).... T57 (Teacher 57) and the analysis process included four phases described below:

First phase: teacher responses to each question in the interview form were examined in depth and separately, responses that included similar or common aspects were marked and coded. 
Second phase: following the coding, similar answers and common points mentioned in the same questions were reexamined to categorize the findings and themes were generated based on the codes. Frequency of each view was calculated and the data were digitalized.

Third phase: the data obtained by analyzing the coded teacher views were written under the themes as direct or indirect quotes. Teacher views that were found interesting by the researchers were directly quoted. Teachers' opinions are expressed in " $\mathrm{f}$ " in the tables.

Fourth phase: the findings obtained by analyzing the data collected with the help of interview forms were interpreted. Possible reasons and results were emphasized during interpretation phase and efforts were made to establish the relationships among the data. For reliability, expert view was sought for the categories after data analysis.

\section{Findings and Interpretations}

\subsection{What School Conflict Means}

Table1. Views regarding concept of school conflicts

\begin{tabular}{|c|c|c|c|}
\hline Main Theme & Sub Category & Justification/Sample Sentences & $\mathbf{f}$ \\
\hline Differences of opinion & $\begin{array}{l}\text { Inability to find common ground } \\
\text { Differences of opinion } \\
\text { Inability to form unity in ideas } \\
\text { Disagreements } \\
\text { Having different views } \\
\text { Clash of ideas } \\
\text { Dissensus }\end{array}$ & $\begin{array}{l}\text { Conflicts are disagreements } \\
\text { parent-teacher-administrator-student (T3), confrontations } \\
\text { due to differences of opinion, believing that only one's own } \\
\text { views and behaviors are correct (T4), Not tolerating } \\
\text { differences of opinion and displaying destructive attitudes at } \\
\text { times of conflicts instead of constructive attitudes (T5) }\end{array}$ & 35 \\
\hline Negative Situation & $\begin{array}{l}\text { Forming groups with like minded } \\
\text { people } \\
\text { Tension } \\
\text { Unconformity } \\
\text { Harming others } \\
\text { Communication gap } \\
\text { Ideological disputes } \\
\text { Prejudices }\end{array}$ & $\begin{array}{l}\text { Conflicts are negative events and situations that cannot be } \\
\text { approved by students and school personnel(T7), They are } \\
\text { problems among the administration and teachers (T6), } \\
\text { Conflicts are harming others in order to prove that you are } \\
\text { right (T10), They are unconformities caused by prejudices } \\
\text { that are born out of communication problems (T13) }\end{array}$ & 34 \\
\hline
\end{tabular}

According to Table 1, teachers who shared their ideas defined school conflicts as differences of opinion and negative circumstances. The teachers who defined conflicts as differences of opinion emphasized the concepts such as inability to find common ground, differences of opinion, inability to form unity in ideas, disagreements, having different views, clash of ideas and dissensus. For teachers who defined conflicts as negative situations emphasized the following concepts: forming groups with like minded people, tension, unconformity, harming others, communication gap, ideological disputes and prejudices. Findings suggest that teachers still have the traditional approach towards the concept of conflicts because the majority of teachers consider conflicts as unnecessary and disturbing situations based on traditional view. Conflicts are considered to be phenomena that hinder the realization of school goals and that harm educators and students. Therefore the majority of teachers do not believe that conflicts at schools can create opportunities to resolve problems related to management. At the same time, meanings that were ascribed to the concept of conflict by teachers were found to be similar to those used in the literature (Rahim, 1985; Luthans, 1992; Şimşek, 2002; Koçel, 2003; Eren, 2003). 


\subsection{Reasons behind School Conflicts}

Table 2. Reasons behind school conflicts

\begin{tabular}{|c|c|c|c|}
\hline Main Theme & Sub Category & Justification/Sample Sentences & f \\
\hline $\begin{array}{l}\text { Lack of } \\
\text { communication }\end{array}$ & $\begin{array}{l}\text { Indifference } \\
\text { Disrespect } \\
\text { Personal judgments } \\
\text { Persistency } \\
\text { Misunderstandings }\end{array}$ & $\begin{array}{l}\text { Not respecting each others' opinions (T24), } \\
\text { Misunderstandings, efforts to prove the accuracy } \\
\text { of one's own views (T26, 31), communication } \\
\text { gaps (T31), different thinking styles (T34), } \\
\text { Disrespect towards other views (T40), Lack of } \\
\text { communication and apathy }(T 45,55),\end{array}$ & 16 \\
\hline Personal & $\begin{array}{l}\text { Unnecessary complaints } \\
\text { High expectations } \\
\text { Dissatisfaction about meeting their desires } \\
\text { Personal ambitions and weaknesses } \\
\text { Dissatisfaction } \\
\text { Complexes } \\
\text { Prejudiced attitudes } \\
\text { Cultural and economic differences } \\
\text { Ignorance } \\
\text { Lack of tolerance }\end{array}$ & $\begin{array}{l}\text { Jealousy (T21), Not undertaking responsibilities } \\
\text { (T29), Conflicts based on personal egos (T36), } \\
\text { Inability to reach maturity (T40), Teachers and } \\
\text { students who have not yet completed personality } \\
\text { development (T46), Personal preferences and } \\
\text { desires (T57) }\end{array}$ & 13 \\
\hline $\begin{array}{l}\text { Political/ } \\
\text { ideological }\end{array}$ & $\begin{array}{l}\text { Respecting different opinions } \\
\text { Lack of tolerance } \\
\text { Insistence on personal judgments }\end{array}$ & $\begin{array}{l}\text { Differences of opinion (T35), Political views } \\
\text { (T48), Current political subjects in the media } \\
\text { (T50), Mostly political discussions (T51), } \\
\text { Political views (T56) }\end{array}$ & 12 \\
\hline Organizational & $\begin{array}{l}\text { Inability to follow rules } \\
\text { Neglect of duty } \\
\text { Negative effects of the social environment } \\
\text { Teaching program } \\
\text { Student absences } \\
\text { Failure in education and training } \\
\text { Unfairness in task distribution } \\
\text { Inability to get to know students }\end{array}$ & $\begin{array}{l}\text { Not following the school rules (T33,32), problems } \\
\text { related to authority gap (T46), conflicts result } \\
\text { from administrators (T49), differences in } \\
\text { educational methods (T53), efforts to adapt lesson } \\
\text { programs according to one's own agenda (T56) }\end{array}$ & 11 \\
\hline
\end{tabular}

According to Table 2, teachers stated lack of communication followed by personal, political/ideological and organizational factors as the reasons of conflicts. Indifference, disrespect, personal judgments, persistency and misunderstandings generate conflicts that are based on communication. Personal reasons that create conflicts are unnecessary complaints, high expectations, dissatisfaction about meeting their expectations/desires, personal ambitions and weaknesses, prejudices, cultural and economic differences, ignorance, lack of tolerance and misunderstandings. Political and ideological conflict reasons are lack of respect towards different opinions, lack of tolerance and insistence on personal judgments while organizational reasons include inability to follow rules, neglect of duty, negative impact of the social environment, student absences, failure in education and training and unjust practices in task distribution. As can be seen from both the main themes and the sub categories, conflicts can be caused by many reasons. Literature also states that classifying conflicts under specific headings is not a correct approach (Huczynski and Buchanan, 1991). However, reasons based on personal characteristics (Özkalp and Kırel, 2001) and based on organization and management structure (Kılınç, 1985) are regarded as the main reasons behind conflicts. Conflicts can also occur due to differences in interpersonal skills and competences, personality characteristics, views, values, moral judgments and emotions as well as communication gaps (Bartol and Martin, 1991). Although the organization and its aims are common, personality types, educational and cultural levels, experiences, skills, emotions, beliefs and thoughts of the staff result in viewing and interpreting the same events and situations differently (Korkmaz, 1994). In addition, problems in communication, the bridge to ensure rapport in a specific structure (Karcioğlu and Alioğulları, 2012), and interaction processes result in conflicts (Erdoğan, 1999). Just like individual differences, political and ideological differences of opinion should be used as a source of enrichment and not as a reason for polarization and enmity. Teachers employed at schools should interact with each other socially to ensure benefits for themselves and for the organization. Otherwise, tensions will occur and peace, collaboration and team spirit will be harmed and an undisciplined environment will materialize. This will result in other conflicts in addition to decreasing performance and motivation and harming the quality of education.

\subsection{Outcomes of School Conflicts}

43 teachers identified negative outcomes whereas 18 teachers identified positive outcomes related to school conflicts. 


\subsection{Negative Outcomes}

Table 3. Negative outcomes of school conflicts

\begin{tabular}{|c|c|c|c|}
\hline Main Theme & Sub Category & Justification/Sample Sentences & $\mathbf{f}$ \\
\hline Psychological & $\begin{array}{l}\text { Anger and tension } \\
\text { Lack of communication } \\
\text { Harming the self and others } \\
\text { Unease } \\
\text { Lack of trust } \\
\text { Feelings of insignificance } \\
\text { Unhappiness, disappointment } \\
\text { Frustration } \\
\text { Stress } \\
\text { Indifference }\end{array}$ & $\begin{array}{l}\text { Conflicts create negative and tense environments, } \\
\text { you cannot work productively in such } \\
\text { environments (T13), (people in conflicts) harm } \\
\text { themselves and the others around them (T10), } \\
\text { Conflicts may create trust issues among } \\
\text { individuals (T30), Uneasiness, getting bored } \\
\text { (T23), Conflicts may result in lack of } \\
\text { communication and stress among individuals } \\
\text { (T11) }\end{array}$ & 26 \\
\hline Social & $\begin{array}{l}\text { Increased animosity and hostility } \\
\text { Lack of tolerance } \\
\text { Violence } \\
\text { Forming groups with like minded } \\
\text { people } \\
\text { Polarization } \\
\text { Enmity } \\
\text { Prejudice }\end{array}$ & $\begin{array}{l}\text { Conflicts may harm the peace of individuals and } \\
\text { the society (T10), Conflicts negatively affect the } \\
\text { motivation of all individuals in educational } \\
\text { environments and decrease success (T16), } \\
\text { Conflicts are unconformities based on prejudices } \\
\text { resulting from lack of communication (T13), } \\
\text { Animosity and hostility start among individuals } \\
\text { (T31), Conflicts generate polarization (T44) }\end{array}$ & 18 \\
\hline Organizational & $\begin{array}{l}\text { Tense and unsettled environment } \\
\text { Weakened cooperation } \\
\text { Damaged team spirit } \\
\text { Forming groups with ideologically like } \\
\text { minded people } \\
\text { Decreased productivity and } \\
\text { performance } \\
\text { Decreased motivation and achievement } \\
\text { Lack of discipline } \\
\text { Dropping out of school } \\
\text { Lack of communication } \\
\text { Decreased school quality } \\
\text { Weakened human relationships } \\
\end{array}$ & $\begin{array}{l}\text { Education and training may be halted (T8), since } \\
\text { it is not possible to meet at common ground, } \\
\text { people form groups with like minded people (T17), } \\
\text { Enthusiasm for work may be diminished (T26), } \\
\text { Conflicts causes tension and harsh measures are } \\
\text { taken towards the administration (T3), An } \\
\text { undisciplined environment is created (T5), } \\
\text { Conflicts end in low morale and lack ofmotivation } \\
\text { (T7), Conflicts create a cold and tense } \\
\text { environment (T13), Bilateral relationships are } \\
\text { weakened (T15), Conflicts create lack of } \\
\text { motivation and generates unrest at educational } \\
\text { environments (T16) }\end{array}$ & 18 \\
\hline
\end{tabular}

According to teacher views presented in Table 3, negative impact of school conflicts manifests themselves psychologically, socially and organizationally. Conflicts can result from individual conflicts, interpersonal conflicts and organizational conflicts. This is related to the fact that individual dimensions of the school environment are more sensitive than its organizational dimensions, its informal aspects are more pronounced than its formal aspects and its field of impact is wider than its field of authority (Bursalıŏlu, 1994). According to teacher views, conflicts create anger, lack of communication, harming the self and others, unease, lack of trust, feelings of insignificance, unhappiness, disappointment, frustration, stress and indifference psychologically. Conflicts which increase negative thoughts and emotions in the personnel are also reflected on the work and decrease motivation. Personnel who cannot control the conflicts do not only reflect these negative results on themselves but also on their colleagues and thereby experiencing breakdowns in their relationships with their colleagues. Socially, conflicts increase animosity and hostility among the personnel and result in lack of tolerance, violence, formation of groups with like minded people, polarization, enmity and prejudices. Break down in relationships among the colleagues bring negative emotions such as lack of trust and suspicions. Organizational results of conflicts are tense and unsettled environments, weakened cooperation, damaged team spirit and communication, forming groups with ideologically like minded people, decreased productivity and performance, decreased motivation and achievement, lack of discipline, increases in drop outs and decreased school quality. Therefore, when conflicts are not effectively managed, the school environment is also negatively affected. In addition to creating waste in terms of effort, time and financial resources, conflicts also result in deviation from the aims and can even end up in leaving the organization (Dinçer and Fidan, 1996). 


\subsection{Positive Outcomes}

Table 4. Positive outcomes of school conflicts

\begin{tabular}{|c|c|c|c|}
\hline Main Theme & Sub Category & Justification/Sample Sentences & $\mathbf{f}$ \\
\hline Personal & $\begin{array}{l}\text { Learning correct behaviors } \\
\text { Noticing mistakes } \\
\text { Noticing different opinions } \\
\text { Ability to consider events from multiple } \\
\text { perspectives } \\
\text { Developing new ideas and methods } \\
\text { Ability to find the truth } \\
\text { Relaxation } \\
\text { Compromise } \\
\text { Increased experiences }\end{array}$ & $\begin{array}{l}\text { We can sometimes learn correct behaviors and } \\
\text { information at the end of the conflict (T10), If the other } \\
\text { party can be convinced rationally based on the } \\
\text { understanding of both parties, consensus can be achieved } \\
\text { from the conflict (T21), Multiple perspectives may be } \\
\text { generated and perspectives may change at the end of the } \\
\text { conflict (T24), Since everyone expresses himself, there is a } \\
\text { relaxed atmosphere (T57), Conflicts provide the } \\
\text { emergence of different views (T17) Conciliatory and } \\
\text { democratic solutions can befound (T45) }\end{array}$ & 10 \\
\hline Social & $\begin{array}{l}\text { Communication } \\
\text { Getting to know each other better } \\
\text { Respecting different views } \\
\text { Ability to compromise } \\
\text { Convincing the parties } \\
\text { Developing understanding }\end{array}$ & $\begin{array}{l}\text { Good competition generates positive results (T25), The } \\
\text { individual may try to do his/her best as a result of the } \\
\text { situation that he/she has encountered (T26), Everyone can } \\
\text { defend their thoughts in the framework of democratic } \\
\text { rules (T49) }\end{array}$ & 10 \\
\hline Organizational & $\begin{array}{l}\text { Realizing/resolving problems } \\
\text { Developing new/different solutions } \\
\text { Increased competitive performance } \\
\text { Attaining better situations } \\
\text { Democratic environment- enriched thoughts } \\
\text { Enlivening life } \\
\text { Meeting at common ground }\end{array}$ & $\begin{array}{l}\text { New ideas and methods can be developed (T11), Problems } \\
\text { can be noticed and efforts can be provided to overcome } \\
\text { them (T7), Common ground can be achieved and solutions } \\
\text { can be obtained (T17), The situation is resolved before it } \\
\text { gets out of hand (T18), Everyone learns about different } \\
\text { views and it is realized that a problem can have more than } \\
\text { one solution (T24), Conflicts generally generate positive } \\
\text { results (T25), Everyone can defend his/her own ideas } \\
\text { based on a democratic framework (T49,45), When } \\
\text { managed well, conflicts can be beneficial for the } \\
\text { organization (T27) }\end{array}$ & 8 \\
\hline
\end{tabular}

According to Table 4, positive outcomes of conflicts are observed in personal, social and organizational aspects. In terms of personal aspects, school conflicts result in learning correct behaviors, realizing mistakes, distinguishing different ideas, regarding events from multiple perspectives, developing new ideas and methods, finding the truth and relaxation. In terms of social aspects, school conflicts result in communication among the staff, better understanding of one another, respecting others' opinions, reaching a consensus and being persuaded. Positive organizational outcomes include realizing the problems, overcoming/resolving existing problems, increasing competitive performance related to development of different and new solutions, creating a democratic environment and enriched views, embellishing the environment and reaching a common solution. Although conflicts are negative situations, they can also be beneficial for both the personnel and the organization. As a matter of fact, conflicts are constructive situations that increase the quality of decisions made by the personnel, motivate them for creativity and innovation, encourage interest and curiosity among the staff, reveal problems and generate self criticism and options for change when anger and tension are allowed to be expressed comfortably and this increases the performance of both the individuals and the group (Ateş, 2015). While conflicts provide flexibility in terms of alternatives of decisions in terms of different behaviors, they also result in the generation of higher level ideas due to clash of opposite ideas (Dinçer and Fidan, 1996; Ertekin, 1993). 


\subsection{Outcomes of School Conflicts on Teachers}

Table 5. Outcomes of school conflicts on teachers

\begin{tabular}{|c|c|c|c|}
\hline Main Theme & Sub Category & Justification/Sample Sentences & f \\
\hline Negative emotions & $\begin{array}{l}\text { Disappointment } \\
\text { Inertia } \\
\text { Reluctance } \\
\text { Insensitivity } \\
\text { Stress } \\
\text { Sorrow } \\
\text { Uneasiness } \\
\text { Tension } \\
\text { Unease }\end{array}$ & $\begin{array}{l}\text { Conflicts decrease the love and respect for the } \\
\text { profession (T16), Conflicts result in loss of trust and } \\
\text { generate a tense environment (T23), Conflicts } \\
\text { generate prejudices and people tend to be more } \\
\text { skeptical (T24), Conflicts create stress (T30), } \\
\text { Conflicts have negative impact since pressure and } \\
\text { authoritarian behaviors generally hurt human ego } \\
\text { (T48), Tension is reflected on the students (T50), } \\
\text { conflicts result in stress and discordant behaviors } \\
\text { (T55) }\end{array}$ & 50 \\
\hline Low performance & $\begin{array}{l}\text { Dislike their professions } \\
\text { Demotivation } \\
\text { Breakdown in communication } \\
\text { Breakdown in morale-motivation } \\
\text { Forming groups with like minded people } \\
\text { Prejudices }\end{array}$ & $\begin{array}{l}\text { Conflicts generate tense environments (T18), Conflicts } \\
\text { decrease teachers' enthusiasm for their jobs (T19), } \\
\text { Motivation decreases (T26), Conflicts cause } \\
\text { teachers to leave their existing posts (T29), conflicts } \\
\text { negatively affect work performance (T31) }\end{array}$ & 39 \\
\hline
\end{tabular}

According to teacher views presented in Table 5, school conflicts generate negative emotions in teachers and result in low performance. Teachers, who experience negative emotions due to conflicts, generally experience disappointment, flatness, unwillingness, insensitivity, stress, sorrow, uneasiness, tension and uneasiness. The teachers who have low performance due to conflicts experience dislike towards their profession, loss of enthusiasm, breakdowns in communication, breakdowns in morale-motivation, prejudice and they form groups with like minded people. These findings present that school conflicts cause negative impact on teachers. Although conflicts are described as situations which have positive outcomes when managed effectively, teacher responses regarding the impact of conflicts generally center on negative outcomes. This finding can be considered as an indication that conflict resolution process is not carried out effectively. As a matter of fact, differences among the school personnel in terms of ideas, goals and practices are necessities for the organization to develop and transform. However, inability to resolve the identified differences causes undesired emotions, thoughts and behaviors. Based on the fact that conflicts will exist everywhere where human beings are found, the main problem for the organization is not how to decrease or eliminate conflicts, but how to resolve them in a constructive manner and how to manage them in a way that will contribute to organizational goals (Düşükcan, 2003). In this context, it is imperative to take necessary precautions to ensure conflicts are not experienced in a degree that would negatively impact teachers.

\subsection{Teacher Reactions during School Conflicts}

Table 6. Teacher reactions during school conflicts

\begin{tabular}{|c|c|c|c|}
\hline Main Theme & Sub Category & Justification/Sample Sentences & $\mathbf{f}$ \\
\hline Discussions & $\begin{array}{l}\text { Defending one's rights } \\
\text { Objecting } \\
\text { Uneasiness } \\
\text { Sorrow } \\
\text { Defending one's ideas } \\
\end{array}$ & $\begin{array}{l}\text { Objections are verbally stated in general (T5), Criticisms, discussions } \\
\text { (T12), Teachers make efforts to defend their thoughts freely (T38), } \\
\text { Increased voice, use of slang, complaints to upper management (T46), } \\
\text { teachers defend their ideas to the full extent (T49) }\end{array}$ & 38 \\
\hline Unresponsiveness & $\begin{array}{l}\text { Keeping quiet } \\
\text { Apathy } \\
\text { Disregard } \\
\text { Severing communication }\end{array}$ & $\begin{array}{l}\text { Sometimes teachers defend their rights but sometimes they let sleeping } \\
\text { dogs lie (T5), Mostly preferring to keep quiet about the conflict (T37) }\end{array}$ & 25 \\
\hline Avoidance & $\begin{array}{l}\text { Compromise } \\
\text { Patience } \\
\text { Understanding } \\
\text { Withdrawal }\end{array}$ & $\begin{array}{l}\text { Staying away so that similar problems are not experienced again (T2), } \\
\text { Teachers try to adapt (to the situation) (T40), teachers are generally } \\
\text { indifferent at times of conflict (T43), Moderate (T45) }\end{array}$ & 24 \\
\hline Violence & $\begin{array}{l}\text { Anger and irritability } \\
\text { Uncontrolled reactions } \\
\text { Complaints } \\
\text { Furiousness }\end{array}$ & $\begin{array}{l}\text { Always complaining (T4), Teachers become angry and furious and look } \\
\text { for opportunities to strike (T10), Teachers give uncontrolled reactions } \\
\text { (T39), far from being restrained (T41) }\end{array}$ & 23 \\
\hline
\end{tabular}

According to Table 6, teacher reactions to school conflicts are in the form of discussion, avoidance, violence or unresponsiveness. Teachers who have discussions in the process defend their rights, object to the situation, defend their ideas and experience uneasiness and unhappiness. This finding shows that discussions are experienced in a negative manner. As a matter of fact, when handled in appropriate platforms, discussions are important opportunities that let both 
the personnel and the interested parties to realize the desires, expectations and misgivings. However, considering the reactions such as uneasiness and unhappiness stated by teachers, it is observed that discussions are experienced in a manner that involves ignoring the expectations and desires of the other party by mostly defending one's position. This can be regarded as an indication that parties in the conflict process are not highly efficient in conflict resolution process. Discussions/arguments experienced in the conflict process are also used in conflict resolution. This finding does not point to a desired situation for teachers who are expected to teach conflict resolution to students. Modern and democratic approach requires teachers to teach problem solving discussion skills to their students at conflict situations but it is highly difficult for teachers to be role models in this regard when they cannot internalize these behaviors themselves. According to the study, teachers who avoid conflicts display patience, compromise, understanding or withdrawal behaviors and this requires one of the parties in the conflict to ignore own expectations or desires and show self sacrifice. Although this solution seems like a temporary solution and it looks like the conflict is resolved, in reality it can create bigger conflicts in the future since the emotions of one of the parties are suppressed. Teachers who react more negatively to conflicts by using violence get angry and irritable, criticize, display uncontrolled reactions make complaints and experience anger. These behaviors are not desired and they will disrupt relationships at school and damage education and training activities. The other reaction displayed by teachers at times of school conflicts is unresponsiveness. In that case teachers keep quiet and display behaviors such as ignoring and disregarding the situation and severing communication. The personnel who ignore the conflicts harm themselves the most. Everyone experiences either negative or positive feelings at times of conflicts. Teachers who ignore conflicts bottle up their emotions and thoughts either knowingly or unknowingly and in the end they withdraw into themselves and feel alone at the school where communication and interactions are highly intense. It should be remembered that this situation will negatively reflect not only on the parties who directly experience the situation but on others as well.

\section{Results and Suggestions}

Conflicts at the school differences of opinion (inability to reach consensus, disagreements, having different ideas etc.) and are negative situations (forming groups with like minded people, unconformity, harming others, breakdowns in communication, ideological clashes and prejudices etc.). School conflicts are caused by lack of communication (indifference, disrespect, personal judgments, persistency, misunderstandings) and personal (unnecessary complaint, high expectations, personal ambitions, prejudices, cultural-economic differences etc.), political/ideological (disrespect for different ideas, intolerance, insistence on personal judgments) and organizational factors (not following the rules, neglect of duty, negative impact of the social environment, curriculum, failure in education, unjust practices at task distribution).

School conflicts have both positive and negative outcomes in terms of psychological, social and organizational aspects. Psychological negative outcomes include anger, lack of communication, harming the self and others, uneasiness, unwillingness, insecurity, feelings of insignificance, sadness, resentment, frustration and stress; social negative outcomes include animosity and hostility, intolerance, violence, forming groups with like minded people, enmity, polarization and organizational negative outcomes include a tense environment, weakened cooperation, breakdowns in communication, ideologically formed groups with like minded people, decreases in productivity, performance, motivation and achievement, an undisciplined environment, quitting the profession and decreased quality of education. Personal positive outcomes of conflicts include learning accurate behaviors, realizing mistakes and different ideas, developing new ideas and methods, arriving at the truth, relaxation and compromise; social positive outcomes of conflicts include enhanced communication, getting to know each other better, respecting others, compromise and organizational positive outcomes of conflicts include realizing problems and finding solutions, developing different and new solutions, increasing competitive performance, creating a democratic environment and enriching the organization.

School conflicts generate negative emotions in teachers and decrease performance. Negative emotions experienced by teachers are disappointment, flatness, unwillingness, insensitivity, stress, sorrow, uneasiness, tension and uneasiness. Factors that decrease teacher performance are related to feelings of dislike towards their profession, loss of enthusiasm, breakdowns in communication, breakdowns in morale-motivation, prejudice and forming groups with like minded people. Reactions of teachers who take are involved in conflicts are in the form of discussions/arguments, avoidance, violence or unresponsiveness.

Based on research findings, the following suggestions are developed: Awareness should be raised for all educators related to effective conflict resolution at schools so that each educator can be involved in the process. Necessary precautions should be taken prior to conflict situations so that conflicts related to educators, school environment and students do not negatively affect the quality of education and training. When managed effectively, conflicts can offer positive contributions to both school goals and to educators and students. Hence, in-service training courses and seminars should be organized so that teachers can better understand school conflicts and manage them effectively. 


\section{References}

Argon, T. (2014). Öğrenciler arasında yaşanan çatışmalar ve çözümü. Ed. Türkan Argon, Şenay S. Nartgün. Sınıf Yönetimi. Ankara: Maya Akademi.

Ateş, M. (2015). Çatışma. http://www.merih.net/m2/lid/wmetate26.htm adresinden 2 ağustos 2055 tarihinde indirilmiştir.

Bartol, K. M., \& Martin, D. C. (1991). Management. New York: Mc Graw-Hill.

Bursalığlu, Z. (1994). Okul yönetiminde yeni yapı ve davranış. Ankara: Pegem Akademi.

Can, H. (2002). Organizasyon ve yönetim. Ankara: Siyasal Kitabevi.

Dinçer, Ö., \& Fidan, Y. (1996). İşletme Yönetimi. İstanbul: Beta Yayınları.

Düşükcan, M. (2003). Örgütlerde Çatışma Yönetimi Sürecinde Örgütsel İletişimin Etkinliği: Kuramsal ve Uygulamalı Bir Çalışma. Yayınlanmamış Doktora Tezi. Konya: Selçuk Üniversitesi Social Bilimler Enstitüsü.

Erdoğan, İ. (1999). İşletme Yönetiminde Örgütsel Davranış. İstanbul: Dönence Basım.

Eren, E. (2003). Yönetim ve Organizasyon. İstanbul: Beta Basım Dağıtım ve Yayınevi.

Ertekin, Y. (1993). Stress ve Yönetim. Ankara: TODAİE.

Huczynski, A., \& Buchanan, D. (1991). Organizational Behaviour. New York: Prentice Hall.

İpek, C. (2000). Örgütsel Çatışma ve Çatışma Yönetiminde Uygulanabilecek Örgüt Geliştirme Araçları. Yönetimde Çağdaş yaklaşımlar. Ed. C. Elma. Ankara: Anı Yayıncılık.

Karcıoğlu, F., \& Alioğulları, Z. D. (2012). Çatışmanın nedenleri ve çatışma yönetim tarzları ilişkisi. Atatürk Üniversitesi İktisadi ve İdari Bilimler Dergisi, 26(3-4), 215-237.

Karip, E. (2000). Çatışma Yönetimi. Ankara: Pegem.

Kılınç, T. (1985). Örgütlerde Çatışma: Mahiyeti ve Nedenleri. İstanbul Üniversitesi İşletme Fakültesi Dergisi, 14(1), 103- 124.

Koçel, T. (2003). İşletme Yöneticiliği. İstanbul: Beta Basım Dağıtım ve Yayınevi.

Korkmaz, S. (1994). Örgütlerde Çatışma Yönetimi ve Verimlilik. MPM Verimlilik Dergisi, 1, 77-94.

Luthans, F. (1992). Organizational Behaviour. USA: McGraw-Hill.

Özkalp E., \& Kırel, Ç. (2001). Örgütsel Davranış. Anadolu Üniversitesi Eğitim Sağlık ve Bilimsel Araştırma Çalışmaları Vakfı Yayınları Yayın No: 149, Eskişehir.

Rahim, M. A. (1983). A Measure of Styles of Handling Interpersonal Conflict. Academy of Management Journal, 26, 368-376. http://dx.doi.org/10.2307/255985

Rahim, M. A. (1985). A Strategy for managing conflict in complex organizations. Human Relations, 38(1), 81-89. http://dx.doi.org/10.1177/001872678503800105

Rahim, M.A. (1992). Managing Conflict in Organizations (2nd Ed.). New York: Praeger.

Robbins S., P., \& Judge, T. A. (2012). Örgütsel Davranış. (Çeviri Editörü: İnci Erdem). Ankara: Nobel Yayınları.

Rubin, J. Z. (1994). Models of conflict in management. Journal of Social Issues, 50(1), 33-45. http://dx.doi.org/10.1111/j.1540-4560.1994.tb02396.x

Şimşek, Ş. (2002). Yönetim ve Organizasyon. Konya: Günay Ofset.

Soyalp, A. (2001). Halk eğitim merkezi müdürlerinin çatışma çözümleme stratejileri. Yayınlanmamış Yüksek Lisans Tezi. Ankara: Gazi Üniversitesi, Eğitim Bilimleri Enstitüsü.

Taştan, N. (2004). Çatışma çözümü ve Akran Arabuluculuğu Eğitimi Programlarının İlköğretim Altıncı Sınıf Öğrencilerinin Çatışma Çözme ve Akran Arabuluculuğu Becerilerine Etkisi. Yayınlanmamış Doktora Tezi. Ankara: Ankara Üniversitesi, Eğitim Bilimleri Enstitüsü.

Thomas, K. (1992). Conflict and Negotiation Processes in Organizations, in M.D. Dunnette and L. M. Hough (eds.), Handbook of Industrial and Organizational Psychology, 2nd ed., Vol.3 (Palo Alto, CA: Consulting Psychologists Press.

Türnüklü, A. (2002). Öğrencileri arasındaki çatışmaların çözümünde problem çözme ve arabuluculuk. Ed. Emin Karip. Sınıf Yönetimi. Ankara: Pegem A Yayınc1lık.

Wall, J., \& Callester, R. (1995). Conflicts and its management. Journal Of Management, 3(2). http://dx.doi.org/10.1177/014920639502100306

\section{$(\mathrm{cc}) \mathrm{BY}$}

This work is licensed under a Creative Commons Attribution 3.0 License. 